\title{
極值統計の適用性評価における留意点および 局部腐食深さデータの活用
}

\author{
永井崇昭*，蔵屋英介*，朝 倉 祝 治* \\ $*$ 横浜国立大学工学部
}

\author{
Critical Discussion on Applicability of Extreme Value Statistics \\ to Localized Corrosion \\ -Use of Individual Depth Data for Evaluation of the Applicability- \\ Takaaki Nagai*, Eisuke Kuraya* and Shukuji Asakura* \\ * Faculty of Engineering, Yokohama National University
}

\begin{abstract}
The applicability of extreme value statistics to localized corrosion was studied based on a actual case. The localized corrosion under tubercles on inner surface of the steel channel in which river water flowed was investigated. Their depths obeyed the distribution of exponential type, while the maximum depths did the double exponential distribution. When the similar data appeared in the previous papers, extreme value statistics was often assumed to be applicable. However, according to the theory of extreme value statistics, the maximum depths are necessary to be sampled from a single population.

Then, it was evaluated by calculating the confidence intervals for the population mean whether the data belong to the same population or not. Moreover, the theoretical distribution of maximum depths was calculated and was compared with the measured one. The results of these analyses showed that extreme value statistics was inapplicable to the present case. Thus, the present case study demonstrates that extreme value statistics is not always applicable to the maximum depths of localized corrosion, even if the depths obey the distribution of exponential type and the maximum depths do the double exponential distribution.
\end{abstract}

Key words : localized corrosion, extreme value statistics, statistical estimation, maximum depths, individual depths, steel channel, river water, tubercle

\section{1. 緒言}

大面積を持つ装置や構造物に生じた最大の局部腐食深 さを極值統計を用いて推定する手法は, 多くの事例解析 により，その有用性が示されてきた。この手法では，極 値統計の理論に基づいて, 小面積の測定区画内の最大局 部腐食深さデータに 2 重指数分布を当てはめるという操 作をする。ただし, 最大局部腐食深さデータに対して 2 重指数分布を当てはめるためには，推定対象の全面に生 じている腐食孔の深さが指数タイプの分布に従っている ことが前提となる。また，極值統計が適用できるのは， 推定対象範囲を分割したすべての区画について，その区

* ₹240-8501 横浜市保土ヶ谷区常盤台 79-5（79-5, Tokiwadai, Hodogaya-ku, Yokohama, 240-8501 Japan)
画内に存在する腐食孔の深さが同一の母集忖からの標本 と見なせる場合に限られる。従って，腐食条件の差異な どにより腐食孔深さの分布が場所によって異なり，測定 位置によってはデータが同一の母集団からの標本と見な せない場合には，それぞれを別の母集団に分類すること が必要とされている11,2)。

データの分類を必要とする事例については，今川ら33 の報告がある。ただし，その分類は腐食条件についての 情報と腐食様態に関する経験的な知識に基づいている。 それに対して，一般的な基準を設けてデー夕を分類する 手順を確立することが必要であるとの指摘もある ${ }^{4)}$ 。一 方, どの場所においても腐食反応を決める腐食条件が均 一で, デー夕の属する母集団が同一であれば, 極值統計 は厳密に適用できる。しかし, 腐食条件が各々の区画で 
均一であるかどうかを厳密に判断することは一般に容易 ではない。このために, 多くの場合, 局部腐食深さデー 夕の属する母集団はすべての区画において同一であると 仮定するか，もしくは厳密な議論を行わないで極值統計 が用いられてきた。そのかわりに適用性の判断は, 局部 腐食深さが指数タイプの分布に従うか, あるいは最大局 部腐食深さデータが 2 重指数分布に従うことを目安とし てきた。全長が長い配管5),6)や面積が大きなタンク底 板 ${ }^{7)}$ に適用された場合でも同様である。しかし，局部腐 食の進展速度は様々な要因に影響される。また, 局部腐 食の平均的な進展速度が同じであっても局部腐食発生ま での期間が場所によって異なれば，ある時刻における局 部腐食深さの分布も違ってくる。従って, 腐食条件に差 が見いだせない場合であっても，局部腐食深さデー夕に 対しては, 母集団が同一であると仮定することは常に適 当とは限らない。この点は, 極值統計を適用する際の大 きな問題であると思われる。特に，長大な構造物では局 部腐食深さの分布が多様化していると考えられる。

この問題に対しては, 統計的手法の利用が考えられ る。岡村 ${ }^{8)}$ は, 化学装置のプロセス配管から得た最大局 部腐食深さデータについて，等分散検定および分散分析 を適用した。これらの統計的検定により，使用場所や形 状の異なる配管から採取したデー夕群が互いのグループ 間で母集団に差があるかどうかが評価されている。統計 的手法にはデー夕の解析のみから母集団の同一性を客観 的に議論できるという利点がある。また，最大局部腐食 深さデータのグループ間の差だけでなく, データ一つ一 つについて同一の母集団からの標本であるかどうかを評 価することもできる。つまり，デー夕を分類すべきかど うかを判断するために必要な腐食条件や腐食様態に関す る情報が不十分であっても，個々のデー夕について母集 団の同一性を判別できるということになる。従って, 統 計的手法を適切に利用すれば，母集団の同一性が不明確 な場合にも極值統計の適用性をより正確に判別できる可 能性があると考えられる。

そこで本研究では, 母平均の信頼区間を推定すること によって, 最大局部腐食深さデータ一つ一つについて母 集団の同一性を評価した。また，測定したすべての局部 腐食深さデー夕を活用することにより, 極值統計の適用 性の判断をより厳密に行うことを試みた。これらの議論 に基づいて, 極值統計が適用できるとしてきた従来の判 断基準の妥当性も検証した。解析した事例は, 水道水之 して利用される河川水（水道原水）を送水する鋼製水路 内面に生じたさびこぶ下の局部腐食である。この鋼製水 路は, 全長が約 $400 \mathrm{~m}$, 接水面積が約 $3100 \mathrm{~m}^{2}$ で, 従来 の報告事例と比較して特に規模が大きい部類に入る。

\section{2. 事例および調查}

\section{1 事例の概要}

净水場が河川などの取水場所から離れている場合, 取 水された水道原水は地中に埋設されたコンクリート製の 水路によって浄水場まで送水される。しかし，峡谷部で は水位を谷の部分まで下げずに送水するために鋼製の水 路が渡されている。鋼製水路には水管橋と水路橋がある が, 本研究で解析した事例は, 全長が約 $400 \mathrm{~m}$, 断面の 幅および高さが $2.8 \mathrm{~m}, 3.4 \mathrm{~m}$ の箱型水路橋である。こ の水路内部には水道原水が通流しており, 調查時点まで の使用期間は 32 年である。水道原水の水質を Table 1 に示す。水路橋の構造材は SS 400 鋼で, 平均水位時に おける水路内面の接水面積は約 $3100 \mathrm{~m}^{2}$ である。水路 橋施工時には内面に膜厚 $0.3 \mathrm{~mm}$ 以上のコールタール エポキシが塗装された。ただし，水路橋施工時以降現在 に至るまで, 内面全体の再塗装やその他の防食は施され ていない。内面全体の再塗装ができないのは，流速 1.8 $\mathrm{m} /$ 秒で流れている水路内部の水道原水を長期にわたっ て停止できないためである。

\section{2 腐食状態および調查方法}

鋼製水路内面は，さびこぶが発生しており局部腐食状 態にあった。さびこぶの下に生じていた腐食孔はすり鉢 状で, 開口部の直径は大きいもので約 $3 \mathrm{~cm}$ であった。 局部腐食深さはデプスゲージを用いて $0.05 \mathrm{~mm}$ の精度 で測定した。また，水路内面は局部腐食を受けた部分以 外には黒い被覆物が残存していた。これは状況から塗装 の一部分と考えられるものであった。ただし，この被覆 物は十分に水分を含んでおり防食機能はないと考えられ る状態であった。

腐食調查は，全長約 $400 \mathrm{~m}$ の箱型水路において，40 $\mathrm{m}$ 間隔の 11 か所の両側面を調查地点とし, 合計 22 の 区画で測定を行った。ただし，水路の底面は排水が完全 でなかったために調査できなかった。各測定地点では， 測定区画面積を $1.8 \mathrm{~m}$ 四方とし, 測定区画内のさびこ ぶの数とさびこぶ下の局部腐食深さを測定した。1つの さびこぶの下に複数の腐食孔があった場合には, 最大深 さの測定値だけを解析に用いた。すなわち，1つのさび こぶに対して 1 つの局部腐食深さデータを得るようにし

Table 1 Water quality (Average through 1995)

\begin{tabular}{cc}
\hline Electric conductivity & $200 \mu \mathrm{S} / \mathrm{cm}$ \\
\hline $\mathrm{pH}$ & 7.9 \\
\hline$\left[\mathrm{Cl}^{-}\right]$ & $11 \mathrm{mg} / \ell$ \\
\hline$\left[\mathrm{SO}_{4}{ }^{2-}\right]$ & $20 \mathrm{mg} / \ell$ \\
\hline Langelier index & -0.6 \\
\hline
\end{tabular}


た。以上の手順によって, 22 の測定区画で合計 191 個 のさびこぶをはがして 191 点の局部腐食深さデータを 得た。

\section{3 調 查結果}

Fig. 1 に水路の片側側面における調查結果を示す。 横軸は水路の端からの位置で測定地点を示している。棒 グラフは $1 \mathrm{~m}^{2}$ あたりのさびこぶの発生個数で，○プ ロットは各地点で測定された局部腐食深さの最大值であ る。本事例では，さびこぶの発生個数および局部腐食の 最大深さが場所によって様々に異なっていた。なお，本 論文中では各地点で測定された局部腐食深さの最大值を 最大值デー夕と呼び，その他の局部腐食樑さデー夕と区 別する。

測定した局部腐食深さの全データ 191 点のヒストグ

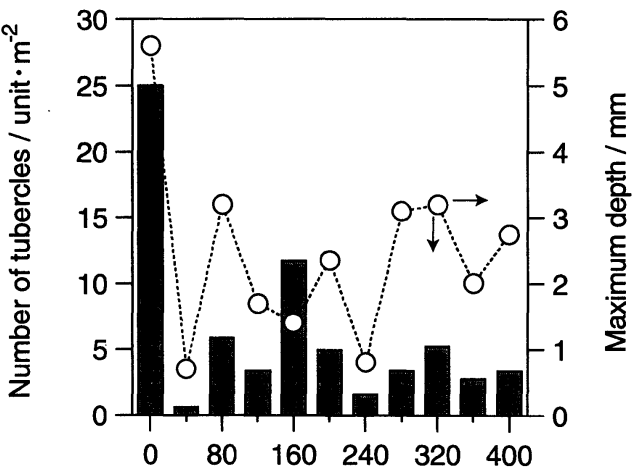

Coordinate of investigated site / $\mathrm{m}$

Fig.1 Maximum depth of localized corrosion and number of tubercles at each of investigated sites. Distance appearing in coordinate was measured from the entrance end of the channel.

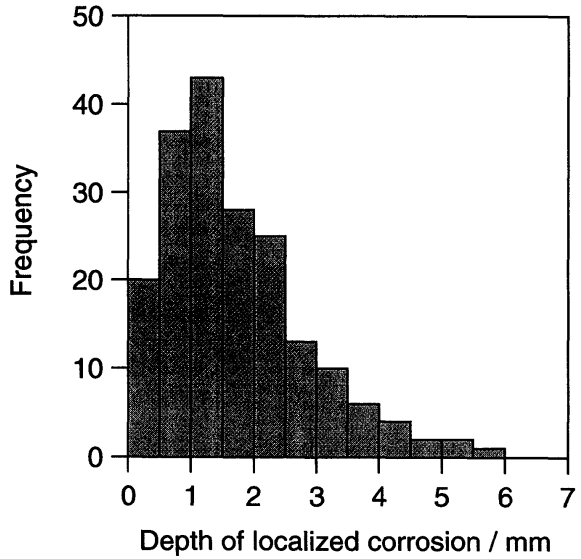

Fig.2 Histogram of all corrosion depths.
ラムを Fig. 2 に示す。炭素鋼に生じたさびこぶ下の局 部腐食深さに関しては，正規分布 ${ }^{9)}$ や指数分布 ${ }^{10)}$ に従 うという報告がある。それに対して本事例の場合は，最 頻值が中央より左側にあって右裾が指数的に減少してい ることから，正規分布と指数分布の中間的な分布をして いる。これを 2 重指数確率紙にプロットするとFig. 3 に示すように良い直線性が得られた。従って，局部腐食 深さは 2 重指数分布に従っていることがわかる。

一方, 測定 1 区画内の局部腐食深さは正規分布に従っ た。平均ランク法により正規確率紙プロットした一例を Fig. 4 に示す。 3 種のプロットはそれぞれ別の測定地 点のデータであるが，いずれも良い直線性を示してい

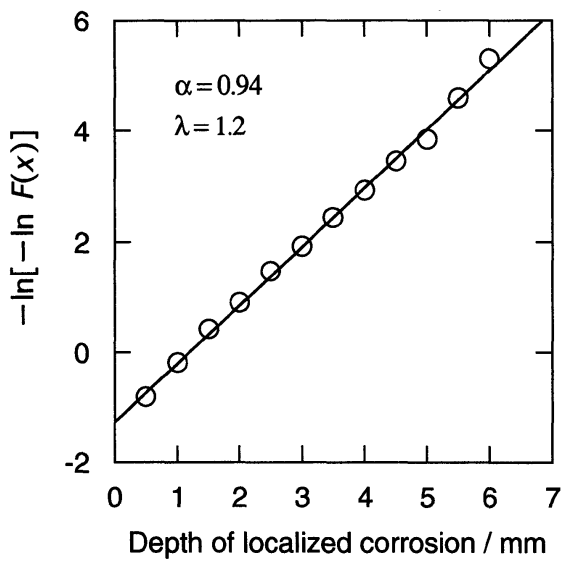

Fig.3 Double exponential probability plot for all the depths included in Fig.2.

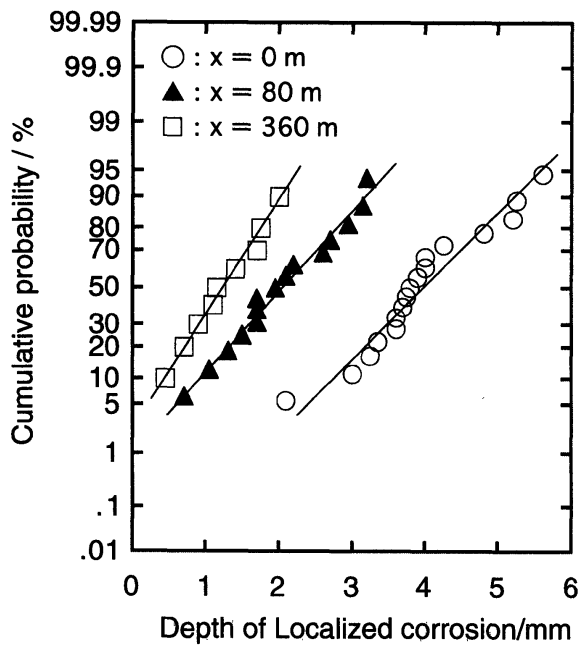

Fig.4 Normal probability plots of the depths measured at a few investigated sites.

$x$ : Distance of the site from the entrance of the channel. 


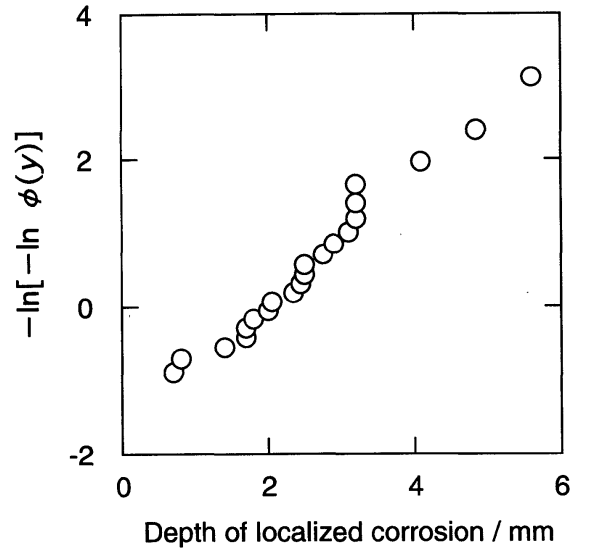

Fig.5 Double exponential probability plot of maximum depth data.

る。ただし，平均はそれぞれ異なっている。

各測定地点で実測した最大值データの 2 重指数確率紙 プロットを Fig. 5 に示す。ただし， 22 の測定地点のう ち 1 地点ではさびこぶが生じていなかったので, 最大值 デー夕数は 21 である。良い直線性を示していることか ら, 最大值デー夕は 2 重指数分布に従っていることがわ かる。

\section{3. 極値統計の適用性の解析}

\section{1 最大值データの理論分布の導出}

本事例では, 測定 1 区画の面積を $1.8 \mathrm{~m}$ 四方とした にもかかわらず 1 区画内のさびこぶ数は平均で 9 個で あった。1区画の測定数が少ないために，この調査から 得られた最大值デー夕を極值の漸近分布である Gumbel 分布に当てはめて最大深さを推定することは適切で はない。しかし，極值統計の理論を適用するための条件 が成立しているかどうかについては議論できる。すなわ ち, $1.8 \mathrm{~m}$ 四方の各測定区画から得られたデー夕が，す べての区画について同一の母集団からの標本と見なせる かどうかについて検定し, 極值統計の適用性評価に関す る留意点を考察する。

まずはじめに，得られた最大值デー夕について検討す る。本事例では, 测定位置によって局部腐食のメカニズ ムが異なるほどの腐食条件の差異はなく，局部腐食深さ の分布は Fig. 2 に示したように一山の単峰型であった。 従って，一見すると局部腐食深さデー夕は単一の母集団 から得られていることが期待される。しかし，Fig. 1 に示したように, 本事例では局部腐食深さの最大值デー 夕が測定地点によって著しく異なっていた。このばらつ きが統計誤差でなく母集団の違いによるものであれば, 極値統計を適用することはできない。

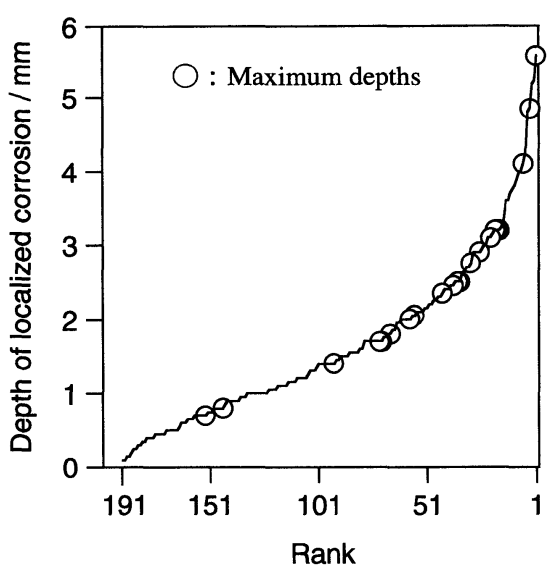

Fig.6 Depths plotted against the rank of 191 samples.

Fig. 6 に, 測定した局部腐食深さの全データ 191 点 を深さの順にプロットした結果を示す。22 の測定区画 から得た全データ 191 点は折れ線で示し, そのうち各 測定区画における最大值データには○を記した。横軸に 示した順位が 1 のデー夕は，実測した局部腐食の中で最 も深い腐食孔のデータである。また，縦軸はその深さが $5.6 \mathrm{~mm}$ であることを示している。図の横軸の順位から 読み取れるように，○で記した最大值データは全体の上 位 50 位以内に半数しか入っていない。極值統計を適用 する場合，最大値デー夕は最大值分布を与えるものでな ければならない。しかし, 得られた最大值デー夕の順位 は，全デー夕の最大值側に位置しているとはいえない。 このことは，最大值データに極值統計を適用できない可 能性があることを示唆している。従って，本事例につい ては, 極值統計の適用性を何らかの方法で評価する必要 があるといえる。しかし，極值統計の適用性を厳密に解 析した報告は見あたらない。そこで, 最大值データが従 うべき理論分布を計算により導出し, 実測した最大值 デー夕の分布と比較することで，極值統計を適用できる かどうかを評価することとした。

ここで, 最大值データが従う理論分布の導出手順を示 しておく ${ }^{11)}$ 。局部腐食深さを確率変数 $X$ とする母集団 が, ある累積分布関数 $F(x)$ に従っているとする。 $F(x)$ からの $n$ 個の標本 $x_{1}, x_{2}, x_{3}, \cdots x_{n}$ の最大值を $x_{\max }$ と すると， $x_{\max }$ もまた確率変数である。この確率変数をあ らためて $Y$ とおくと, $Y=\max \left\{X_{1}, X_{2}, X_{3}, \cdots, X_{n}\right\}$ であって, その累積分布関数 $\Phi(y)$ は

$$
\Phi(y)=\{F(y)\}^{n}
$$

で与えられる。 $F(x)$ が指数分布や正規分布のように 指数タイプの分布であれば, (1)式は $n \rightarrow \infty て ゙$ 


$$
\Phi(y)=\lim _{n \rightarrow \infty}\{F(y)\}^{n}=\exp \left\{-\exp \left(-\frac{y-\lambda}{\alpha}\right)\right\}
$$

の 2 重指数分布 (Gumbel 分布) に漸近する。ここで $\alpha$ は尺度パラメー夕，入は位置パラメータである。これ は, 元の分布 $F(x)$ が明らかでない場合でも, 最大值 デー夕を 2 重指数分布に当てはめて解析できることを示 している点で重要である。ただし， $F(x)$ がわかる場合 には，(1)式により最大值データが従う理論分布の厳密 形が求められる。例えば $F(x)$ が 2 重指数分布の場合 には，(1)式を解析的に計算することができる。Fig. 3 に示したように，本事例では実測した局部腐食樑さが 2 重指数分布に従っていたので, 母集団の分布 $F(x)$ も 2 重指数分布であるとして解析することとした。2 重指 数分布の累積分布関数は,

$$
F(x)=\exp \left\{-\exp \left(-\frac{x-\lambda}{\alpha}\right)\right\}
$$

で表されるから, 確率変数 $X$ を $Y$ に置き換えて(1)式 に代入すると $\Phi(y)$ は(4)式のように求められる。

$$
\begin{aligned}
\Phi(y) & =\left[\exp \left\{-\exp \left(-\frac{y-\lambda}{\alpha}\right)\right\}\right]^{n} \\
& =\exp \left\{-\exp \left(-\frac{y-\lambda-\alpha \ln n}{\alpha}\right)\right\}
\end{aligned}
$$

これを変形すると

$$
-\ln [-\ln \{\Phi(y)\}]=\frac{y}{\alpha}-\frac{\lambda+\alpha \ln n}{\alpha}
$$

となる。（4)式からわかるように， $n$ 個のデー夕を測定 して得られる最大值の分布は, 尺度パラメータが元の分 布と同じで, 位置パラメータが $\alpha \ln n$ だけ大きくなる。 また，（5）式からわかるように, 縦軸に $-\ln [-\ln \{\Phi$ $(y)\}$ ], 横軸に $y$ をとった 2 重指数確率紙においては, 元の分布の直線と傾きが同じで, 横軸方向に $\ln n$ だけ 平行移動した直線となる。

\section{2 実測したすべての最大值データに対する適用性}

Fig. 7 に, 実測したすべての最大値データ 21 点およ び最大值データの理論分布の 2 重指数確率紙プロットを 示す。○が実測した最大值データのプロットで, 破線が 理論分布である。最大值データの理論分布は, (1)式に示 したように母集団分布 $F(x)$ が与えられれば計算によ り求められる。そこで, Fig. 3 に示した局部腐食深さ の実測分布が母集団分布に等しいと仮定して, この理論 分布を導出した。Fig. 7 では例として, $n=1,3,5,10$, 20 とそれぞれに Fig. 3 の当てはめ線より読みとった $\alpha$ $=0.94, \lambda=1.2$ を(5)式に代入して求めた結果を 5 本 の破線で示した。最大值デー夕の従う分布は標本数 $n$ の大きさに依存し, $n$ が大きいほど右に平行移動した直 線となることがわかる。なお, $n=1$ として求めた分布 はFig. 3 に示した局部腐食樑さの実測分布と同じであ

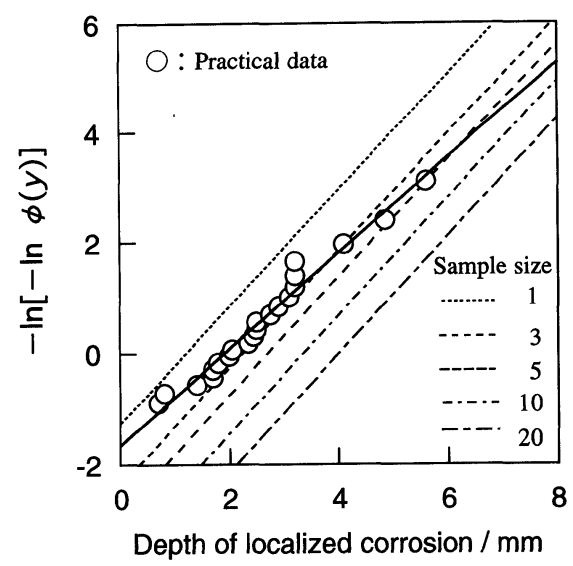

Fig.7 Comparison of practical and theoretical maximum depths plotted on double exponential probability paper. Dashed lines show theoretical extreme value distributions with different sample sizes (number of pits), ranging $n=1$ to 20 .

る。

ここで, ○プロットと破線を比較してわかるように, 実測した最大值データの分布は, 傾きが理論分布と異 なっている。また, 最大值デー夕は各測定区画において 平均で 9 個の局部腐食深さを測定して得たものである。

しかし, 標本数 $n=9$ の理論分布とは一致せず, むしろ $n$ の小さい側にあって最大值の分布を与えているとはい えないことがわかる。このような最大值デー夕の実測分 布と理論分布の不一致は, 局部腐食深さデータと最大值 データの間に，(1)式の関係が成立していないことを示 している。この不一致の原因としては, 最大值データが 同一の母集団から得られた標本でないことが考えられ る。その場合には，極值統計を本事例に対して適用する ことはできない。

\section{3 母集団の同一性の評価}

あるいくつかのデータ群がいずれも同じ母集団からの 標本と見なせるかどうかは, 統計的手法により判別でき る。その 1 つが, 標本から母集団の平均である母平均の 区間を推定するという手法である。この手法により推定 された母平均の区間が異なれば，各デー夕群は互いに異 なる母平均を持つ母集団からの標本と見なされる。すな わち, 母集団は同一ではないと判断できる。本事例では, Fig. 4 に示したように測定 1 区画における局部腐食深 さデー夕は正規分布に従った。そこで, 測定 1 区画にお ける局部腐食深さデー夕は正規分布に従う母集団からの 標本であるとして, 各測定区画ごとのデー夕について母 平均の信頼区間を推定した。信頼度 0.99 で推定された 区間を Fig. 8 の棒グラフで示す。ただし，標本数が少 


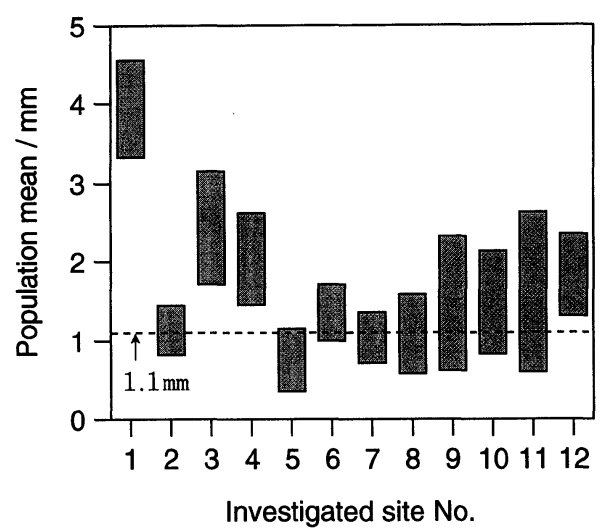

Fig.8 99\% confidence interval for population mean.

ないと精度が低下し推定される区間が広くなるため, 結 果は 1 区画の測定数が $10 〜 17$ 個の範囲にあった 12 の 地点についてのみ示した。母平均の信頼区間は, 測定区 画によっては互いに重なる部分がないことから，この 12 か所の測定区画から得られたデー夕は，すべてにつ いて同一の母平均を持つ母集団からの標本とは見なせな いことがわかる。

\section{4 同一の母集団に分類した最大值データに対する 適用性}

次に, 母平均の信頼区間の推定結果を用いて，母集団 が同一と見なせるデー夕を分類する。Fig. 8 において, 例えば母平均が $1.1 \mathrm{~mm}$ の位置に引いた点線は, 各棒 グラフと 8 か所の測定区画について重なる。これによ り，母平均の信頼区間に $1.1 \mathrm{~mm}$ が含まれる 8 か所の 測定区画を選び出し，デー夕を分類した。分類した局部 腐食深さデータ 93 点と最大值データ 8 点の 2 重指数確 率紙プロットを Fig. 9 に示す。局部腐食深さデー夕に ついてはムプロットで, 最大值データについては○フ ロットで示した。いずれも良い直線性を示しており，2 重指数分布に従っていることがわかる。破線は, 最大值 デー夕の理論分布である。これは， $\Delta$ プロットの当ては め線より読み取った $\alpha=0.58, \lambda=0.57$ と 1 区画の測 定数の平均值 $n=12$ を(5)式に代入して求めた。○フ ロットで示した実測の最大值データの分布は理論分布と よく一致している。この一致は, 局部腐食深さデータと 最大値デー夕の間に，(1)式に示した関係が成立している ことを示している。従って, 分類したデー夕については 極值統計の理論が成立していることがわかる。

Fig. 7 と Fig. 9 を比較してわかるように, Fig. 8 に 示した方法で母集団が同一と見なせるデー夕を分類する ことにより，極值統計の理論が成り立つように改善され た。このことは逆に, 分類前の Fig. 7 に示したデータ に関しては，母集団の同一性という前提条件が満たされ

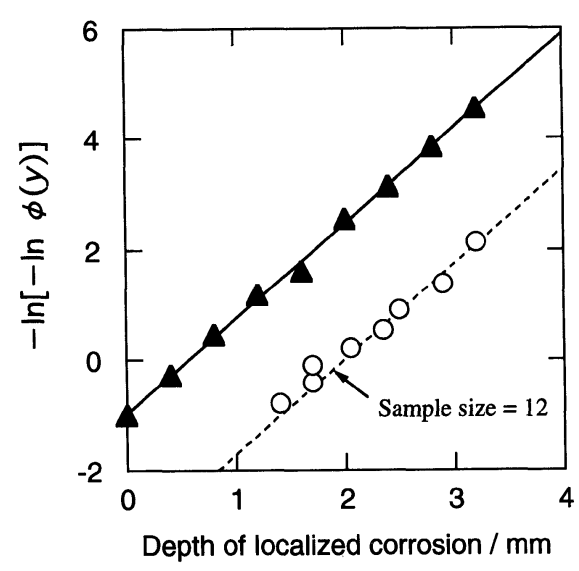

Fig.9 Comparison of practical maximum depths (O) and theoretical ones (---) on double exponential probability paper. Line $-\boldsymbol{A}$ is the distribution of the individual depths obtained by practical measurements.

ていなかったために, 極值統計の理論が成立していな かったことを示している。従って, 本事例に対しては極 值統計を適用できないと判断できる。

ここで, もう 1 つ重要なことは, Fig. 7 で示したデー 夕が極值統計理論の成立しないデータであるにもかかわ らず，Fig. 7 のプロットで示したように最大值デー 夕が 2 重指数分布によく従っているという点である。従 来, 最大值デー夕が 2 重指数分布に従っているかどうか は，極值統計の適用性を判断する 1 つの目安であった。 しかし, 以上の解析結果は, 最大值データが 2 重指数分 布に従っても，極值統計を適用できない場合があること を示している。

\section{4. 極值統計を適用する場合の留意点}

\section{1 極值統計の適用性の判断基準}

本事例では, 最大值データが 2 重指数分布によく従っ ていたこと以外にも，極值統計を本事例に対して適用で きると判断されるような要件が満たされていた。第 1 に, 局部腐食のメカニズムが本質的に異なるような腐食 条件の差異は無く, かつ Fig. 2 に示したように局部腐 食深さの分布は単峰型であった。従って, 一見すると局 部腐食深さデー夕は単一の母集団からの標本と見なせる 状況にあった。第 2 には, 局部腐食深さは指数夕イプの 分布に従っており, 最大值デー夕を 2 重指数分布に当て はめるための前提条件が成り立っていた。従来の多くの 報告事例では, これらの要件が満たされていれば, 極值 統計が適用されてきた。しかし, Fig. 8 に示したよう に母平均の信頼区間を推定すると, 測定区画によっては 局部腐食深さ分布の母集団が異なると判断された。さら 
に, Fig. 7 に示したように，最大值データの実測分布 と理論分布を比較することによって, 極值統計が適用で きないことが示された。以上の解析結果は, 極值統計が 適用できるかどうかについての従来の判断の目安は, 常 には妥当ではないことを示している。従って，極值統計 の啇用性は, 母集団の同一性を考慮して, より厳密に評 価する必要があるといえる。本論文で示した母平均の信 頼区間の推定および最大值データの実測分布と理論分布 の比較は，その一例である。

\section{2 母集団が異なる原因}

本事例では, さびこぶの発生個数と局部腐食深さ分布 の両方が測定位置によって著しく異なっていた。この理 由については明らかではないが，水路の構造との対応は なく，水路内面が接している溶液環境はどの場所でも同 じであることを考虑すると, 内面塗装が原因と考えられ た。塗装の状態は場所によって不均一で, 良好な部分と 不良な部分がランダムに存在するであろうから，局部腐 食の程度が測定位置によって様々であったことを説明で きる。例えば, 塗膜の欠陥部分が局部腐食の起点となっ たとすると,さびこぶの発生個数が多い場所では, 塗膜 の欠陷部分が多かったと考えられる。また，深い腐食孔 が生じているのは, 局部腐食発生までの誘導期間が短 かったか, 強いカソードにより局部腐食の進展速度が速 かったためと考えることができる。誘導期間やカソード の強さについても, 塗装の状態が影響するものと思われ る。従って, 局部腐食深さの分布が場所によって様々に 異なった原因は, 局部腐食のメカニズムが異なるためで はなく，塗装の初期状態およびその後の劣化の程度が 違っていたためと推察した。ただし, 内面調查時点にお ける外面観察からは塗装状態と局部腐食の程度の関連は 見いだせなかった。

よころで，塗装の不均一性は一般に避けるここができ ない。しかも，場所によって様々に異なりうる。従って， 塗装された事例に対して極値統計を適用しょうとする場 合には，十分な配慮が必要になると思われる。

\section{3 測定 1 区画の最小面積の決定}

極值統計解析による最大局部腐食深さの推定手法を適 用する場合，1区画の面積は少なくともその区画内に局 部腐食個数が 20 個程度はあるような大きさであること が必要とされている2)。これは, 極值の漸近分布である Gumbel 分布に最大值デー夕を当てはめるための前提 条件である。ただし，本事例のように場所によって局部 腐食深さの分布が様々に異なる場合には，1区画の面積 についてはさらに注意して決定する必要がある。本事例 の腐食状態を模式的に表すと Fig.10のようになる。 Fig.10 は, 局部腐食深さの程度が 4 段階に異なってお り，かつその配置がランダムである場合を示している。

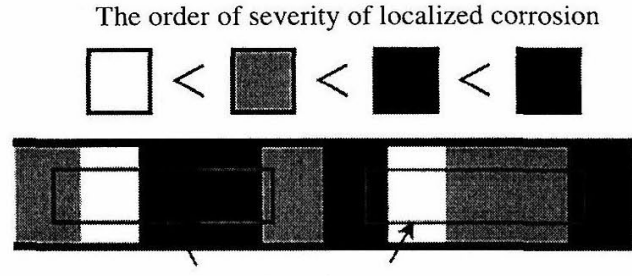

Investigated area

Fig.10 Illustration for non-uniform distribution of severity of localized corrosion.

このような場合には，1区画の面積が小さいと区画ごと によって局部腐食深さの分布が異なるので極值統計を適 用できない。しかしながら，Fig.10の四角枠で示した ように測定区画の面積を十分に大きくとれば，区画ごと の分布の差は次第に小さくなるので極值統計が適用でき るようになると考えられる。実際, 局部腐食深さの程度 が場所によってランダムに異なる場合でも，1区画の面 樍を大きくとることによって極值統計解析を商用できた という報告がある ${ }^{3)}$ 。従って，推定対象範国を分割した すべての区画について，その区画内の局部腐食深さの分 布が均質となるように，すなわちデー夕が同一の母集団 からの標本と見なせるという条件を満たすように測定 1 区画の最小面積を決定する必要があるといえる。

本事例で調查した $1.8 \mathrm{~m}$ 四方の測定区画面積は, 極 値統計を適用した他の事例33,6),7)における測定区画面積 よりも大きい。このことは, 従来の報告では $1.8 \mathrm{~m}$ 四 方以下の面積でもその区画内に十分な数の局部腐食個数 が存在したというだけでなく，各測定区画において局部 腐食深さの分布が均質であったということも示唆してい る。一方, 本事例の場合では测定 1 区画を $1.8 \mathrm{~m}$ 四方 としたが各測定区画の分布は均質ではなく，極值統計を 適用できなかった。従って, 測定区画の面積は $1.8 \mathrm{~m}$ 四方よりも相当大きくする必要があったといえる。とこ ろで, 本事例において局部腐食深さの分布が場所によっ て様々であった原因は塗装の不均一性と考えられた。 従って, 塗装の不均一性による影響が予想される局部腐 食の事例に対して極值統計を適用しようとする場合に は，従来の報告例以上に测定区画面積を大きくとること を考慮する必要があると思われる。また，1区画の局部 腐食個数が 20 個以上となるように面積を決定したとし ても，母集団分布が均質化したかどうかについては検定 した上で，極值統計を適用することが望ましいと思われ る。

\section{5. 結 論}

水道原水を送水する鋼製水路内面に生じたさびこぶ下 
の局部腐食の事例を解析し，極值統計の適用性評価に関 して以下の知見を得た。

（1）局部腐食のメカニズムが異なるような腐食条件 の差異がなく, 局部腐食深さデー夕の分布が単峰型の場 合でも, 局部腐食深さの最大值デー夕が同一の母集団か らの標本と見なすことはできないことがある。

（2） 局部腐食深さデータが指数タイプの分布に従い, あるいはまた局部腐食深さの最大值データが 2 重指数分 布に従う場合でも，極值統計を適用できないことがあ る。従って, 局部腐食深さの最大值デー夕に対する極值 統計の適用性は，より厳密な手続きで評価する必要があ る。

（3）極值統計の適用性の評価には, 局部腐食深さ データが有効に利用できる。本事例解析では，母集団の 同一性を客観的に評価するために，母平均の信頼区間を 推定する手法を用いた。また, 極値統計の適用性は, 最 大値デー夕の実測分布と理論分布を比較することでより 厳密に評価した。その結果, 信頼度 0.99 で推定された 母平均の信頼区間が互いに一致しないデー夕に対して は，極值統計を適用できなかった。

（4）本事例では測定 1 区画の面積を $1.8 \mathrm{~m}$ 四方とし たが, 測定区画内の局部腐食深さの分布は場所によって 様々であった。この原因としては, 塗装状態の不均一性 が考えられた。仮に, 測定区画面積を大きくすることで
区画ごとの分布が均質化し，極值統計解析を適用できる ようになるとしても，その面積は $1.8 \mathrm{~m}$ 四方よりも相 当大きくする必要があると予想された。本事例のように 塗装状態の不均一性の影響があると考えられる事例で は，測定区画面積についての十分な配慮が必要である。

(Manuscript received August 27, 1998; in final form December 11, 1998)

\section{参 考 文 献}

１）腐食防食協会編：「装置材料の寿命予測入門一極 值統計の腐食への適用」, p. 20, 丸善 (1984).

2 ）腐食防食協会60-1分科会：防食技術，37，768 (1988).

3 ) 今川博之, 松野健三 : 材料, 38, 823 (1988).

$4)$ T. Shibata: J. Res. Natl. Inst. Stand. Technol., 99, 327 (1994).

5 ）小向 茂, 笠原晃明: 材料之環境, 43, 258(1994).

6 ) 山本一雄: 第 58 回腐食防食シンポジウム資料, p. 14，腐食防食協会（1984）。

7 ) 荒木了一, 三浦昭夫, 堺 松成, 横山二郎, 横矢 重治 : 圧力技術, 24, 124 (1986).

8 ) 岡村辰夫 : 化学装置, 35, 60 (1993).

9 ) 正村克己, 松島 厳: 材料, 36, 47 (1987).

10）高崎新一, 紺谷武司: 材料, 36, 72 (1987).

11）伊藤 學, 亀田弘行, 黒田勝彦, 藤野陽三 共訳 : 「土木・建築のための確率・統計の応用」, p. 207， 丸善 (1988). 